\title{
A new early Miocene fossil genus from Dominican amber extends the Eastern Asia distribution of Paricanini (Hemiptera: Fulgoromorpha: Tropiduchidae) to the Neotropics
}

\author{
Thierry Bourgoin, Rong-Rong Wang, Jacek Szwedo, Xin-Yu Li, and Xi Chen
}

\begin{abstract}
A new extinct genus and species, Seeteascanopia arcabucana gen. et sp. nov. are described from early Miocene Dominican amber. Its placement in the planthopper family Tropiduchidae, tribe Paricanini is discussed. It represents the second described New World fossil of Tropiduchidae for which a review of all fossil taxa is provided. The family is regarded as a Laurasian lineage and, in absence of a phylogenetical framework, both a Palaeocene and a more recent Oligocene dispersion scenario are discussed for the tribe to reach Hispaniola. These two possible scenarios are also suggested for another early Miocene Dominican fossil amber of Tropiduchidae of the tribe Neommatissini that exhibits a similar bipolar distribution.
\end{abstract}

Thierry Bourgoin. Institut Systématique, Evolution, Biodiversité (ISYEB), UMR 7205 MNHN-CNRSSorbonne Université-EPHE, Museum National d'Histoire Naturelle, CP50, 57 rue Cuvier, 75005, Paris, France. Co-corresponding author. thierry.bourgoin@mnhn.fr ORCID 0000-0001-9277-2478

Rong-Rong Wang. Institute of Zoology, Chinese Academy of Sciences, 1 Beichen West Road, Chaoyang District, Beijing 100101, P.R. China. Co-corresponding author. rongrong@ioz.ac.cn

ORCID 0000-0002-9667-2738

Jacek Szwedo. Laboratory of Evolutionary Entomology and Museum of Amber Inclusions, Department of Invertebrate Zoology and Parasitology, University of Gdańsk, 59 Wita Stwosza Street, 80-308 Gdańsk, Poland. jacek.szwedo@biol.ug.edu.pl

ORCID 0000-0002-2796-9538

Xin-Yu Li. College of Nature Conservation, Beijing Forestry University, Beijing 100083, P. R. China.

136179665@qq.com

ORCID 0000-0001-5136-0303

Xi Chen. Institute of Automation, Chinese Academy of Sciences, 95 Zhongguancun East Road, Haidian District, Beijing 100190, P.R. China. xi.chen@ia.ac.cn

ORCID 000-0002-6922-2838

http://zoobank.org/97F7EE4C-1BC7-4D4C-B045-4C39B87B553A

Bourgoin, Thierry, Wang, Rong-Rong, Szwedo, Jacek, Li, Xin-Yu, and Chen, Xi. 2019. A new early Miocene fossil genus from Dominican amber extends the Eastern Asia distribution of Paricanini (Hemiptera: Fulgoromorpha: Tropiduchidae) to the Neotropics. Palaeontologia Electronica 22.3.77. 1-15. https://doi.org/10.26879/958 palaeo-electronica.org/content/2019/2840-dominican-amber-tropiduchidae

Copyright: December 2019 Paleontological Society.

This is an open access article distributed under the terms of Attribution-NonCommercial-ShareAlike 4.0 International (CC BY-NC-SA 4.0 ), which permits users to copy and redistribute the material in any medium or format, provided it is not used for commercial purposes and the original author and source are credited, with indications if any changes are made.

creativecommons.org/licenses/by-nc-sa/4.0/ 
Keywords: early Miocene; Dominican amber; Hispaniola Island; Laurasian lineage; new genus; new species

Submission: 7 January 2019. Acceptance: 8 November 2019.

\section{INTRODUCTION}

With 186 genera and 659 species currently recognized, Tropiduchidae Stål, 1866, remains a small family within the Fulgoromorpha, respectively representing only $7.7 \%$ and $4.8 \%$ of the known planthopper genera and species (Bourgoin, 2019). The family probably originated in the Upper Cretaceous (Bourgoin et al., 2018; Szwedo, 2018), but the oldest fossil is from the Eocene (55.8 - 33.9 m.y.a.) when the family was already diversified. It is divided into two subfamilies: Elicinae Melichar, 1915, comprising five tribes and Tropiduchinae Stål, 1866, with 19 tribes (Gnezdilov et al., 2016; Bourgoin, 2019). In the latter, three tribes are represented in Central America from where the new fossil is described: Tangiini Melichar, 1914, Remosini Fennah, 1982, and Cyphoceratopini Fennah, 1982, all together circling the Gulf of Mexico and the Caribbean Sea and present in the Greater Antilles. Emilianini Shcherbakov, 2006, is documented with a unique fossil taxon from Colorado, USA, and the Alcestini Melichar, 1914, is a southern taxon, with northern limits at Trinidad-Tobago (Fennah, 1945a, 1945b, 1945c; Bourgoin, 2019).

Another tribe of Tropiduchinae, Paricanini Melichar 1914, is reported from temperate (China, Hainan) and tropical Asia (Brummitt, 2001). It is distributed into the Oriental Wallace's biogeographic regions (Wallace, 1876) and in the Oriental zoogeographic realm (Holt et al., 2013). The taxon is a small group, recently revised (Stroiński et al., 2015), represented by only 10 species in five genera: the type genus Paricana Melichar, 1914 (two species), Paricanoides Liang, 2003 (three species), Leusaba Walker, 1857 (three species), and two monospecific genera: Stacota Stål, 1859, and Lukabales Stroiński and Szwedo, 2015. The tribe has been reported from China, Eastern Asia, Indian Subcontinent, Indo-China, and Malesia, with a latitudinal profile confined between North equatorial to North tropical climatic zones (Bourgoin, 2019). This distribution corresponds mainly to the tropical and subtropical moist broadleaf forest biome more or less surrounded by subtropical moist forest and tropical rain forest terrestrial biomes in the south (Porse, 2008). Biological data for the tribe remains, unfortunately, almost absent.
Only Constant and Pham (2014) reported that all species of Paricanoides currently collected in Vietnam and China were found at an altitude between 500 and $1500 \mathrm{~m}$ in tropical mountain evergreen forests.

Only seven tropiduchid fossils have currently been described, all from Eocene Baltic amber except Emiliana alexandri Shcherbakov, 2006, from early to early middle Eocene in Colorado (Shcherbakov, 2006). The purpose of this paper is to describe a new early middle Miocene Tropiduchidae amber fossil of Dominican Republic, representing a new Neotropical genus of the tribe Paricanini, whose extant distribution occurs only in southeast Asia.

\section{MATERIAL AND METHODS}

The specimen was observed using a Zeiss Discovery V.12 stereomicroscope in normal reflected and transmitted light. Photographs of habitus were taken with a Canon EOS 50D digital camera associated with a Leica Z16 APO microscope. Digital images were then imported into Adobe Photoshop 8.0 for labelling and plate composition.

Three-dimentional (3D) X-ray micro-computed tomography scans with synchrotron radiation $(\mu \mathrm{CT})$ were performed at the Carl Zeiss (Shanghai) Co., Ltd., with a Zeiss Xradia510 Versa. Beam strength was $40 \mathrm{KeV}$ and magnification of the optical system was adjusted to yield images in resolution of $3.0 \mu \mathrm{m}$.

Three-dimensional structures were reconstructed using Amira 6.0 (Visage Imaging, Berlin, Germany). The data files were then transferred to MAYA 2017 (Autodesk Inc., CA, USA) in order to use the smoothing function, specific display, and rendering options implemented in this software. Final images were assembled and arranged with Adobe Photoshop CS6, (Adobe Inc., CA, USA).

Fourier Transformed Infrared Spectra (FTIR) spectra of the amber specimen MNHN.F.A58689 (Figure 1) was obtained at the CRC laboratory (CRCC - MNHN, France), with a ATR-FTIR Nicolet 6700 Spectrophotometer equipped with a diamond ATR accessory (Attenuated Total Reflectance): 


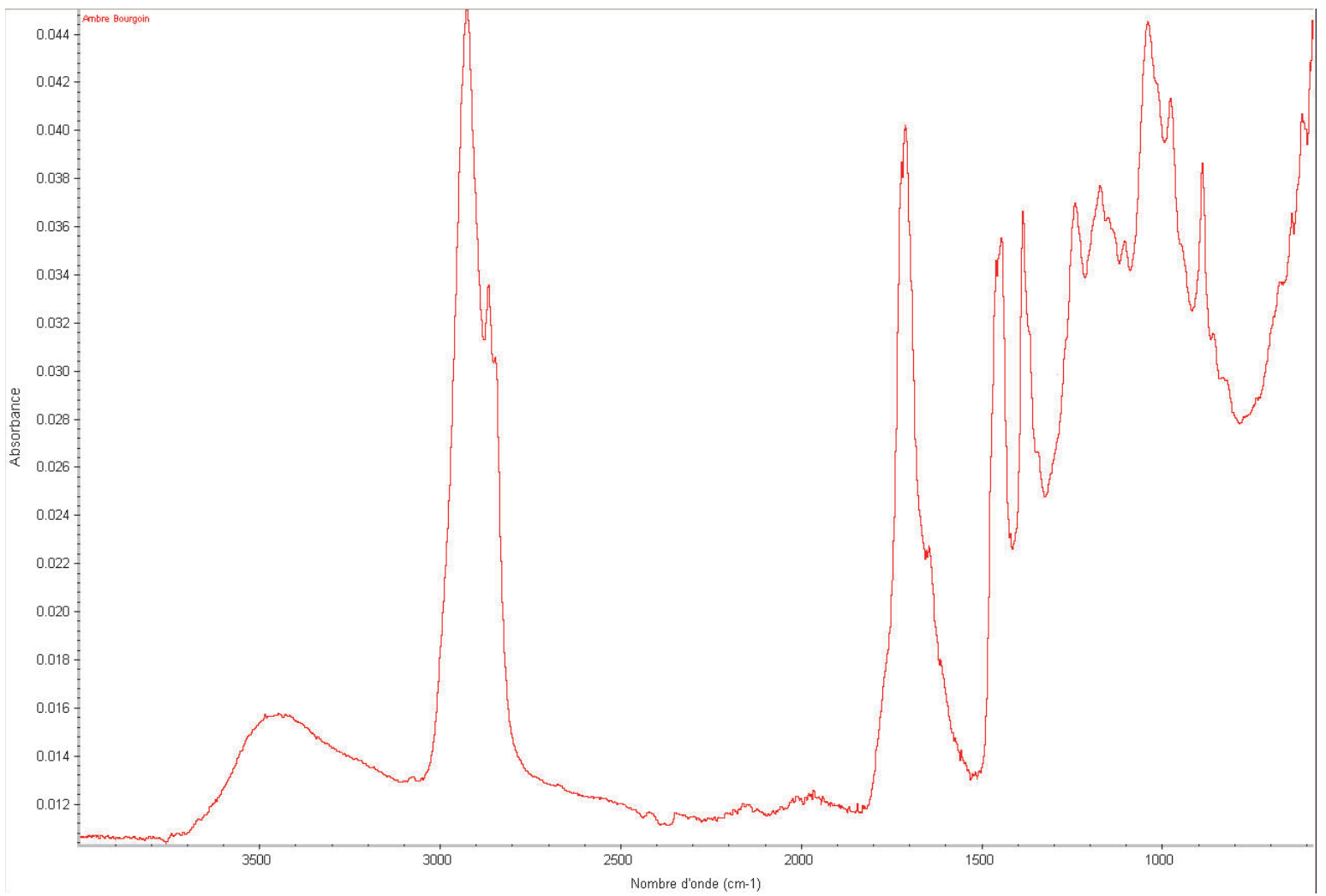

FIGURE 1. Fourier Transformed Infrared Spectra (FT-IR) spectra of the amber specimen MNHN.F.A58689. Wavenumber $\left(\mathrm{cm}^{-1}\right)$ as abscissa.

registered with resolution $4 \mathrm{~cm} \_1$, baseline correction and advanced ATR correction.

The fossil was generously donated by Alex Brown to the first author, and it has been deposited in the Museum national d'Histoire naturelle, Paris (MNHN). It belongs to the same series in which another interesting Augilini Baker, 1915, planthopper fossil (Caliscelidae Amyot and Serville, 1843) was recently described (Bourgoin et al., 2016).

Morphological terminology follows that of Bourgoin and Huang (1990) and Bourgoin (1993) for male and female genitalia, respectively, and Bourgoin et al. (2015) for tegmina.

\section{SYSTEMATIC PALAEONTOLOGY}

Order HEMIPTERA Linnaeus, 1758

Family TROPIDUCHIDAE Stål, 1866

Subfamily TROPIDUCHINAE Stål, 1866

Tribe PARICANINI Melichar, 1914

Type genus. Paricana Walker, 1857

Other included genera. Paricanoides Liang, 2003, Leusaba Walker 1857, Stacota Stal, 1859, Lukabales Stroiński and Szwedo, 2015 (Stroiński et al., 2015), Seeteascanopia gen. nov. (fossil).
Distribution. From India (Dehli, Melichar, 1914) and Sri Lanka to China (Hainan), Eastern Asia Japan islands (Bonin Islands), Malesia (Borneo, Sumatra), Indo-China (Vietnam, Cambodia, Thailand, Philippines) (Bourgoin, 2019). Fossil specimen is from Hispaniola Island, Dominican Republic.

Seeteascanopia gen. nov. Bourgoin and Wang zoobank.org/CA0E5555-1326-440A-8F80-8F3FFB2DFF72

Type species. Seeteascanopia arcabucana sp. nov. by monotypy and present designation.

Etymology. The generic name is derived from a free association and transliteration of 'CT-scan', and the Taino's name 'Opia' meaning spirit for the indigenous inhabitants of the Hispaniola, as CTscan observations are crucial in the placement of the fossil in the Asian Paricanini tribe. Gender: feminine.

Diagnosis. In general appearance similar to some other genera of Paricanini, namely Stacota and Leusaba, but differs by the following characters: vertex anteriorly angulate (almost straight in Stacota and slightly convex in Leusaba), broader than long (almost quadrate in Stacota); frontal lateral 
carina almost parallel ventrally (as in Paricana and Paricanoides; divergent in Stacota and Leusaba). Prothorax strongly produced forward, angulate anteriorly (as in Stacota, rounded and wider in Leusaba) almost reaching anterior margin of compound eyes (only mid-level in Stacota and Leusaba), narrowed behind eyes (as in Stacota, wider in Leusaba). Mesonotum was at least twice longer than wide between anteriorly concave lateral carinae at their wider separation (transverse in Paricanoides); lateral carina posteriorly parallel (as Leusaba, convergent in Paricana, Stacota or divergent in Paricanoides). Mesoscutellum V-shaped, triangular (as Stacota, wide and rounded in Paricana and Leusaba, wide and pointed in Paricanoides). Tegmina with anterior and posterior margins clearly diverging; CuA forking late in its last third before nodal line with a short $\mathrm{C} 5$, about twice as long as wide, shorter than other Paricanini genera. Gonostyli surpassing anal tube (itself long in lateral view), elongated and robust, dorsal tooth-like process robust before middle of gonostyle dorsal margin.

Description. Head with vertex almost three times broader than long in mid line; vertex with disc depressed and median carina triangularly widened at base; median carina of frons cuneate, widened but not obsolete. Head in profile acutely $\left(45^{\circ}\right)$ rounding into frons, the border between vertex and frons thickened. Head, pronotum, and mesonotal disc carinae darkly colored, not concolorous with the body distinctly clearer. Pronotum with disc elevated, median carina slightly widened at base. Mesonotum with disc clearly separated by lateral carinae, lateral carinae fused with median carina anteriorly. Tegmina membranous, with two distinct transversal lines - nodal line and post nodal line; costal area developed, narrow, with apex exceeding tip of clavus. Stem ScP+R forked slightly apicad of stem MP forking at nodal line; stem CuA forked distinctly basad, but apicad of claval veins junction; Stem ScP+RA 1 with additional branches emitted to margin; clavus with apex exceeding half of tegmen length, tornus long; claval veins Pcu and $A_{1}$ fused slightly basad of half of clavus length. Hind coxa with distinct, spinose coxal process. Hind tibia with three lateral spines and five apical teeth.

Seeteascanopia arcabucana sp. nov. Wang and Bourgoin

Figure 2, Figure 3, Figure 4

zoobank.org/02669480-8892-46DF-B9A8-7A80CA750A5B
Material. Holotype, male, Dominican amber, inclusion number $\mathrm{n}^{\circ}$ MNHN.F.A58689, deposited in Museum National d'Histoire naturelle, Paris, France; leg. A. Brown, 2012. Specimen well preserved, slightly distorted, with apical portions of hind legs missing. Syninclusions: Hymenoptera: Formicidae, male specimen (apud Octostruma sp., sec. A. Nel det.); bubbles of air.

Etymology. Specific epithet freely derived from the Taino word 'arcabuco' - meaning forest.

Age and occurrence. Early Miocene. Hispaniola, Dominican Republic, Cordiliera Septentrional, La Bucara Mine. Amber from La Búcara mine belongs to the La Toca Formation group of mines (Penney, 2010). It is dated (Iturralde-Vinent, 2001) in the late early to early middle Miocene, around $16 \mathrm{Ma}$ (Burdigalian), the first and longest warming period during the Miocene (Foster et al., 2012; Henrot et al., 2017).

Diagnosis. As for genus since it is the only included species and additionally: tegmen with branches RP and $\mathrm{M}_{4}$ forked at apical line; branch $M_{1}$ forked distad of apical line. Anteriorly, lateroand mediofrontal, medio clypeal carinae marked with red color. Dorsally, carinae of vertex, median and posterior margin of pronotum and disc of mesonotum highlighted from distinctly paler testaceous ground color with thin dark brown to blackish coloration.

Description. Total length $7.5 \mathrm{~mm}$. Head with compound eyes narrower than pronotum $(1.16 \mathrm{~mm}$ wide); anterior margin of head arcuate. Head in profile acutely passing to frons (at angle ca. $45^{\circ}$ ), the border tumidly strengthened. Vertex about three times as wide as long in mid line $(0.64 \mathrm{~mm}$ and $0.21 \mathrm{~mm}$ respectively); anterior margin of vertex arcuate, elevated; lateral margins straight, elevated, slightly converging anteriad; posterior margin angularly concave, carinately elevated; disc of vertex depressed; median carina triangularly widened at base, with apex reaching anterior margin of vertex.

Frons longer than broad, in mid line $1.28 \mathrm{~mm}$ long, about $1.28 \mathrm{~mm}$ long at lateral margins, 0.64 $\mathrm{mm}$ wide; lateral margins carinate, slightly elevated, subparallel to the level of antennae, then slightly diverging and converging towards frontoclypeal suture; median carina cuneate, broadened. Clypeus about $0.57 \mathrm{~mm}$ long, $0.37 \mathrm{~mm}$ wide at base, with indistinct median eminence, angulately curved at prolongations of lateral margins of frons. Rostrum reaching mid coxae; apical segment about 2.5 times as long as wide, shorter than the subapical one. Postocular tumosity present. Lat- 

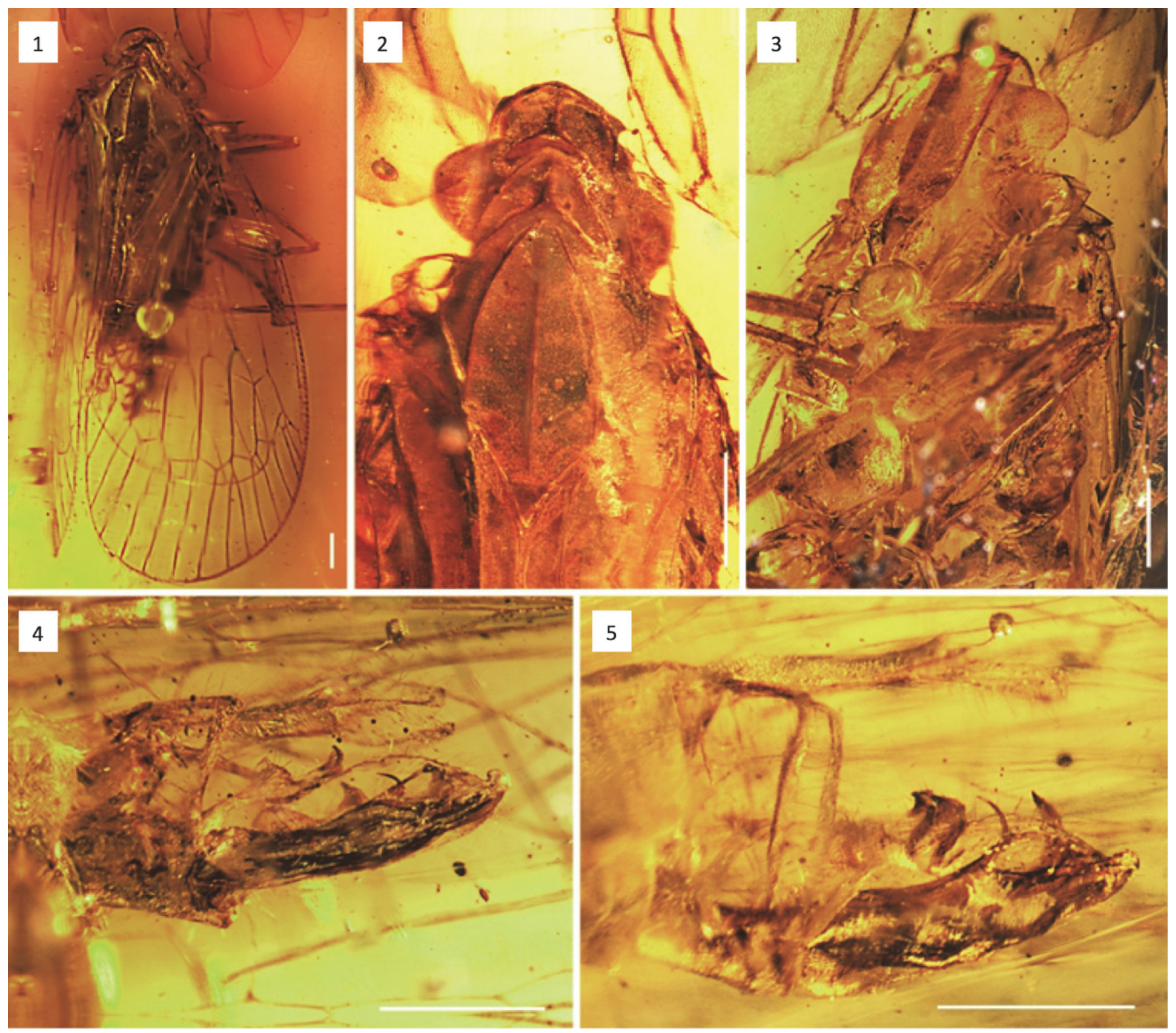

FIGURE 2. Seeteascanopia arcabucana gen. nov. sp. nov. Wang and Bourgoin (Holotype). 1. Dorsal habitus. 2. Pronotum and mesonotum, dorsal view. 3. Head, lateral view. 4. Male genitalia, left view. 5. Gonostyli and endosome, left view. Scale bars equal $0.5 \mathrm{~mm}$.

eral ocelli present. Antennal fovea with elevated margins, scape short, pedicel clavate, slightly compressed with plate organs present since its base (Figure 4.4), arista emerging in lower half, about $0.57 \mathrm{~mm}$ long.

Pronotum $0.29 \mathrm{~mm}$ long in mid line, $0.67 \mathrm{~mm}$ long in total, $1.53 \mathrm{~mm}$ wide. Disc of pronotum elevated, delimited by carinae; median carina widened at base, anterior margin narrowly arcuate; posterior margin deeply angulately concave; disc of pronotum elevated; postocular area of pronotum with two lateral carinae.

Mesonotum about as long $(1.43 \mathrm{~mm})$ as wide $(1.40 \mathrm{~mm})$, with disc elevated, flat, delimited by lateral carinae, and lateral portions sloping down. Lat- eral carinae arcuately converging anteriad, fused with median carina, posteriorly reaching posterior margin of mesonotum.

Tegulae distinct, carinate.

Tegmen $6 \mathrm{~mm}$ long, about $2.13 \mathrm{~mm}$ wide, membranous, with distinct venation, nodal and apical lines present; longitudinal veins not nearing setae; tegmen narrowing basally, widest at level of nodal line; anteroapical angle widely arcuate; posteroapical angle arcuate; postclaval margin long. Costal margin curved at very base, then almost straight to level of nodal line. Costal area present, narrow, without transverse veinlets, veins $\mathrm{Pc}+\mathrm{CP}$ parallel to costal margin (vein CA), slightly widened at apex; apex of costal area exceeding apex of cla- 
1



2

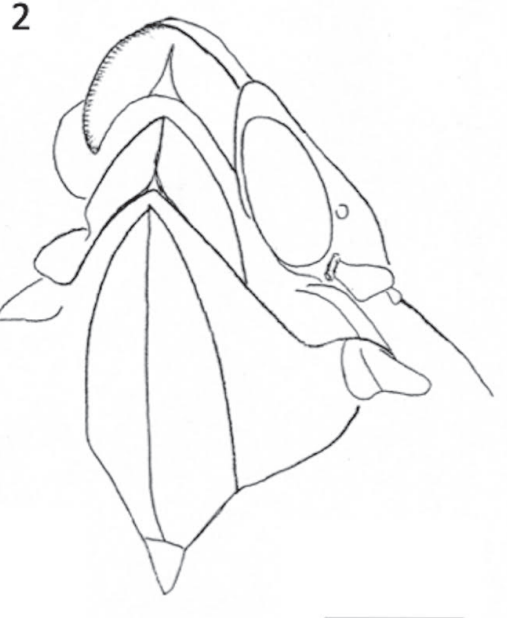

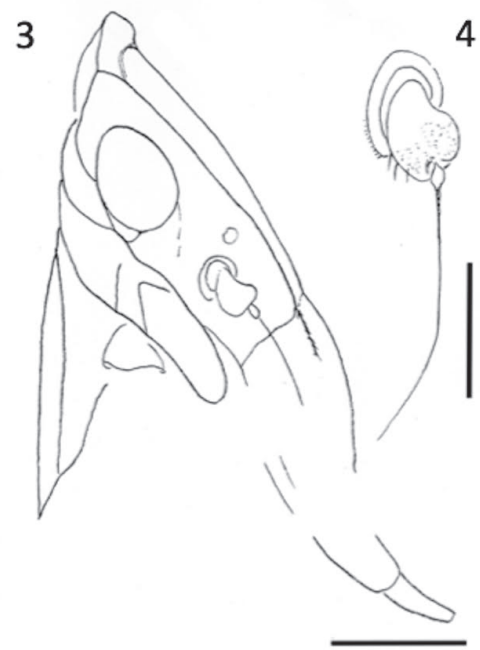

4



6

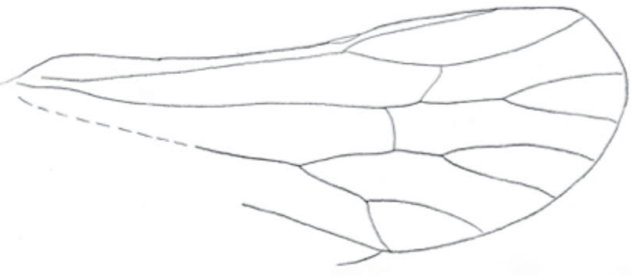

8

7

8

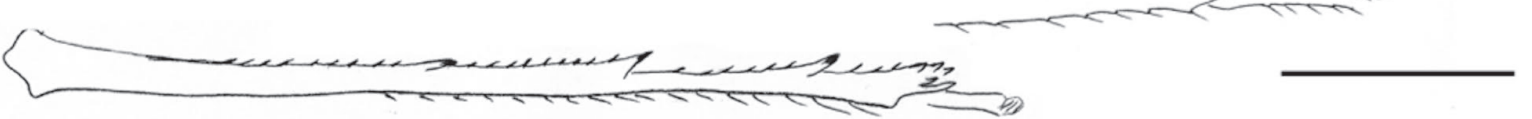

9


FIGURE 3. Seeteascanopia arcabucana gen. nov. sp. nov. Wang and Bourgoin (Holotype). 1. Head, pronotum and mesonotum, dorsal view. 2, 3. Head, antenna, pronotum and mesonotum, lateral view. 4. Right antenna. 5. Right forewing. 6. Right hindwing. 7. Right hind leg. 8. Spines on tibiae. 9. Male genitalia, left view. 10. Gonostyli and endosome, left view. 11. Apex of aedeagus. Scale bars equal $1-3,6-7=0.5 \mathrm{~mm} ; 4-5=1 \mathrm{~mm} ; 8-11=0.25 \mathrm{~mm}$. 


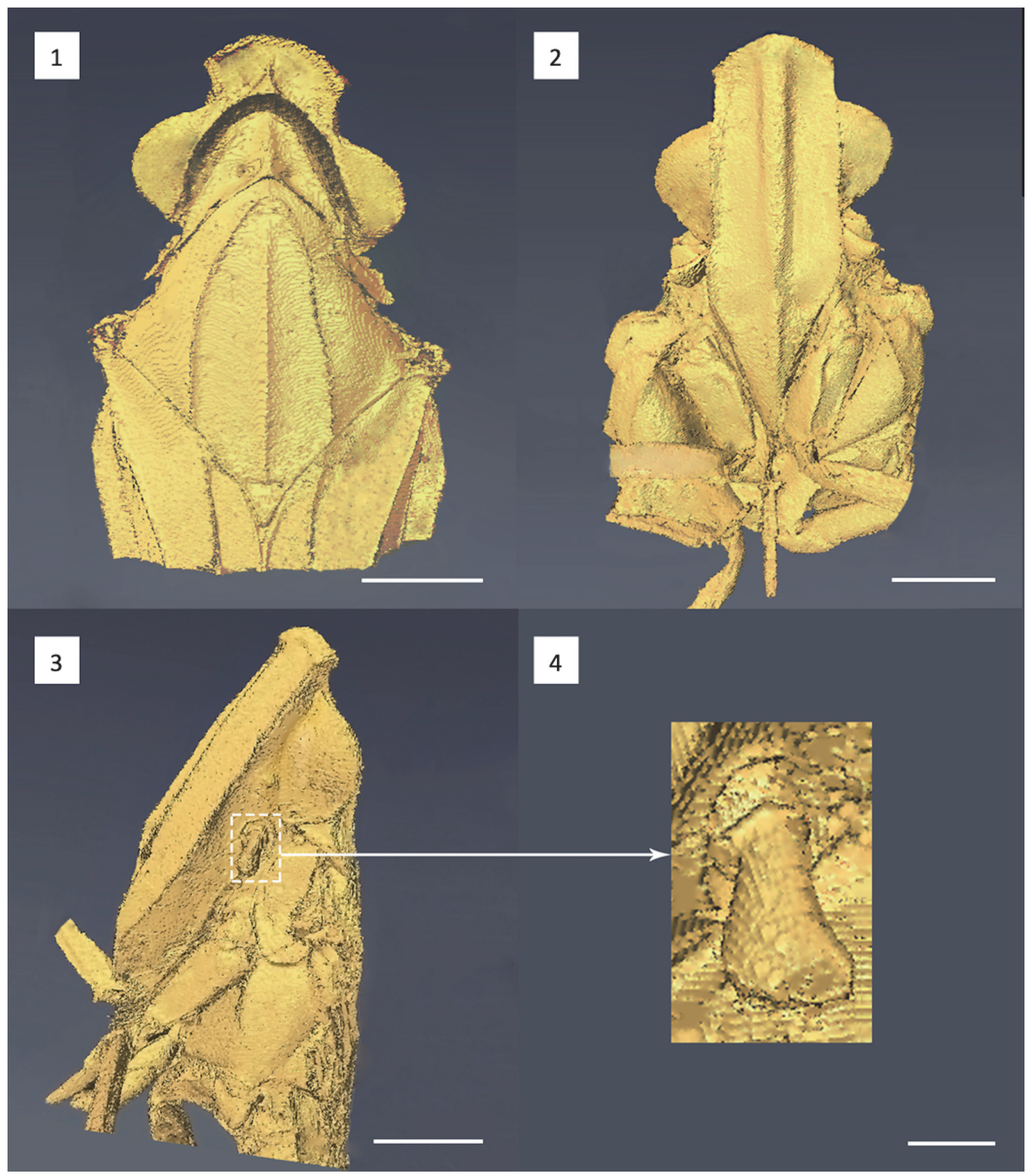

FIGURE 4. 3D reconstructions of Seeteascanopia arcabucana gen. nov. sp. nov. Wang and Bourgoin (Holotype). 1. Head, pronotum and mesonotum, dorsal view. 2. Frons. 3. Head, antenna, pronotum and mesonotum, lateral view. 4. Magnification of left antenna. Scale bars equal $1-3=0.5 \mathrm{~mm}, 4=0.1 \mathrm{~mm}$.

vus; the space between veins of costal area slightly sclerotized - giving impression of strengthened costal margin. Basal cell elongate, more than twice as long as wide. Stems $S c P+R$ and MP leaving basal cell with a short common stalk, stem CuA distinctly curved mediad at exit from basal cell. Stem $\mathrm{ScP}+\mathrm{R}$ not forked before nodal line; branch $\mathrm{ScP}+\mathrm{RA}_{1}$ reaching costal area just before apex, emitting two additional branches to the margin; branch $\mathrm{RA}_{2}$ single; branch RP forked at level of 
apical line. Stem MP forked at apical line, slightly basad of stem ScP+R forking; branch $\mathrm{MP}_{1+2}$ forked at level of apical line, branch $\mathrm{MP}_{1}$ single, branch $\mathrm{MP}_{2}$ forked apicad of apical line; branch $\mathrm{MP}_{3}$ single to the margin; branch $\mathrm{MP}_{4}$ forked at level of apical line. Stem CuA forked in its last third before nodal line, apicad of claval veins junction; branch $\mathrm{CuA}_{1}$ forked at level of apical line; branch $\mathrm{CuA}_{2}$ forked at level of claval apex, terminal $\mathrm{CuA}_{2 \mathrm{a}}$ arcuately curved mediad, branch $\mathrm{CuA}_{2 b}$ straight (variability: on the right tegmen terminal $\mathrm{CuA}_{2 b}$ is very short). Clavus exceeding half of tegmen length; claval veins Pcu and $A_{1}$ fused slightly basad of half of length of clavus. Nodal transverse veinlet $r-m$ oblique, in line with nodal veinlet $m$-cua; nodal veinlet icua shifted slightly apicad, at level of nodal veinlet $r-m$; nodal veinlet icu very short, perpendicular. Costal cell without transverse veinlets or granules, more than twice as wide as costal area. Cell C1 about as long as cell C5. Subapical cells about as long as apical cells; 16 apical open cells between apex of costal area and apex of clavus.

Hind wing shorter than tegmen; costal margin convex at base than straight, apical angle widely angulate. Stem $\mathrm{ScP}+\mathrm{R}$ forked slightly apical do stem CuA forking, terminals ScP+RA and RP single; terminal $\mathrm{ScP}+\mathrm{RA} \mathrm{A}_{1}$ reaching margin at level of stem MP forking, terminal RP reaching margin basad of apex of hind wing. Stem MP forked at level of terminal $\mathrm{ScP}+\mathrm{RA}_{1}$ tip, apical of veinlets $r p$ $m p$ and $m p$-cua. Stem CuA forked basad of stem $\mathrm{ScP}+\mathrm{R}$ forking, branches $\mathrm{CuA}_{1}$ and $\mathrm{CuA}_{2}$ forked before margin; stem CuP single, reaching margin close to the terminal CuA2b. Veinlet $r p-m p$ apicad of veinlet $m p$-cua, slightly obliquely sigmoid; veinlet mp-cua almost straight, at level of branch $\mathrm{CuA}_{2}$ forking.

Profemur and fore tibia similar in length; profemur flattened, with row of short spines ventrally; protibia subqadrate; protarsus $0.47 \mathrm{~mm}$ long, basal and apical tarsomeres $0.18 \mathrm{~mm}$ long, apical tarsomere with tarsal claws $0.29 \mathrm{~mm}$ long, slightly longer than combined length of basi- and mid tarsomeres. Mesofemur $1.2 \mathrm{~mm}$ long, flattened; mesotibia $1.43 \mathrm{~mm}$ long; mesotarsus $0.5 \mathrm{~mm}$ long, basal and apical tarsomeres $0.2 \mathrm{~mm}$ long, apical tarsomere $0.4 \mathrm{~mm}$ long, longer than combined length of basi- and mid tarsomeres. Metacoxa with distinct spinose, acute process; metafemur 1.36 $\mathrm{mm}$ long, metatibia $2.75 \mathrm{~mm}$ long, subquadrate, with three lateral spines, distributed at similar dis- tances each other, first apicad of half of tibia length, second at distad $1 / 3$ of tibia length, and third in apical $1 / 7$ of tibia length, apex of tibia with five apical teeth. Metatibiotarsal formula: 3-5/?/2 (metatarsi absent).

Pygofer laterally compressed, $0.35 \mathrm{~mm}$ long in middle (ventral side) about $0.45 \mathrm{~mm}$ long in lateral view; posterior margin almost straight, with slight elongation at dorsal margin; margin with few long, thin setae. Anal tube elongate, about 0.96 $\mathrm{mm}$ long; anal with posterior margin excavate, lateral margins diverging apicad, apical portion spatulate at apex; anus placed slightly apicad of half of anal tube length; anal style elongate.

Male genital styles not fused at base, about $1.13 \mathrm{~mm}$ long, about 2.5 times as long as broad; ventral margin almost straight, covered with dispersed, long, thin setae, small spatulate process at apex; dorsal margin arcuate, with a few sparse long, thin setae, spinose-lobate process in the middle, lobate process more basad. Aedeagus with sclerotized, spinose, curved process in apical portion and lobate, slight sclerotized expansion at apex.

\section{DISCUSSION}

\section{Placement of Seeteascanopia gen. nov. in Paricanini}

Seeteascanopia gen. nov. is only represented by single male specimen, which does not allow formal testing of its phylogenetic placement within the so-called 'typical tropiduchids' (Gnezdilov, 2013). These Tropiduchinae are characterised by elongate gonoplacs bearing teeth and triangular posterior connective lamina of gonapophyses IX, versus the other subfamily, Elicinae Melichar, 1915, characterized by rounded gonoplacs without teeth and elongate posterior connective lamina of gonapophyses IX (Gnezdilov, 2013). However, its general conformation, the hyperpterous tegmina with distinct nodal and subnodal lines and the regular metatarsal spinulation exclude the fossil from any Elicinae tribes currently recognized.

Nine tropiduchid genera from three different tribes in Tropiduchinae have been reported from Hispaniola, from which the new fossil is described: four Cyphoceratopini (Cyphoceratops Uhler, 1901, Parahydriena Muir, 1924, Tangiopsis Uhler, 1901 and Tangyria Uhler, 1901), three Remosini (Monopsis Spinola, 1839, Neurometa Guérin-Méneville, 1865, Remosa Distant, 1906) and one in each Tangiini subtribe: Neotangiina Fennah, 1982 (Pelitropis Van Duzee, 1908) and Tangiina Meli- 
char, 1914 (Tangella Metcalf and Bruner, 1930). Together with the Amazonian Alcestini Melichar, 1914, those three Caribbean tribes form a welldefined group of taxa characterized by gonostyli less than 2.7 times as long as wide in lateral view (a probable plesiomorphy) and the second antennal segment with plate organs only present in the apical half of the pedicel (a possible synapomorphy). Both of these characters are absent in Seeteascanopia gen. nov. Its tegmina venation with first forking of ScP+RP and MP at nodal line also excludes Seeteascanopia gen. nov. from the fossil tribe Emilianini, the only other tribe of New World Tropiduchinae.

Outside Nearctic tribes, Tropiduchinae with a three-spined tibia and plate organs extending to the base of the pedicel form an important group of taxa. The apomorphic late forking of ScP+RP (not before the nodal line), the unicarinated frons, the translucent tegmen and its venation (and the relatively apomorphic short Pcu cell) successively lead to the last $14^{\text {th }}$ couplet of Fennah 1982's key separating Paricanini from Isporisini Fennah, 1982. Seeteascanopia gen. nov. appears relatively similar to Leusaba, with which it shares the vertex conformation, the long mesonotum and its lateral carinae parallel posteriorly, the tegmen widening to distal quarter and broadly rounding apically. Its clearly V-shaped mesoscutellum would appear to exclude it from Paricanini according to Fennah's 1982 key. However, while this is a character state for Isporisini, it is also clearly present in the Paricanini genus Stacota (Stroiński et al., 2015: fig. 62) and, therefore, homoplasic instead of being diagnostic in separating the two taxa. The less controversial character to separate the two tribes is probably the apomorphic elongate gonostyli, straight, at least three time as long as broad in Isporisini as provided by Fennah in its Table 1 (1982: 635). Seeteascanopia gen. nov. gonostyli are also elongated (longer than anal tube), but they remain clearly broader than in Isporisini.

Accordingly, based on 1) the plesiomorphic state of the antennal sensilla and apomorphic long gonostyli of the fossil, which exclude the taxon from the extant Neotropical tribes Cyphoceratopini, Remosini, Tangiini and Alcestini, 2) the apomorphic tegmen conformation and venation and 3) the combination of the other wing characters, we classified the new fossil in Paricanini, (which is probably a paraphyletic taxon with respect to Isporisini).

\section{A New Tropiduchidae Fossil}

Since the establishment of the family, several fossils were originally described in Tropiduchidae, but subsequently removed (Szwedo et al., 2004). The Eocene Lithopsis fimbriata Scudder, 1878 was transferred to Flatidae (Lewis and Heikes, 1991), then to Fulgoroidea incertae sedis (Carpenter, 1992) and is now considered as a Nogodinidae (Shcherbakov, 2006). The Upper Triassic genus Mesodiphthera Tillyard, 1920 from Queensland, still mentioned as Tropiduchidae by Metcalf and Wade (1966), was placed in Scytinopteridae by Evans (1956) and then in Cicadoprosbolidae by Hamilton (1992). The Upper Permian genus Prosbole Handlirsch, 1904 was transferred for some time to Tropiduchidae by Muir (1923), but is now regarded as part of the Cicadomorpha (Prosboloidea: Prosbolidae) (Shcherbakov, 1984). According to Szwedo et al. (2004), a possible Tropiduchidae was illustrated (F-346) as a Cixiidae in Wu (1996). It might represent a new genus apud Neommatissus Muir, 1913 (Neommatissini Fennah, 1982) according to Shcherbakov (2006). Interestingly, this fossil also belongs to the Dominican amber, whereas the tribe is currently distributed through Southeast Asia down to New Caledonia (Bourgoin, 2019).

It is, therefore, only in 2000 that Szwedo described the first Tropiduchidae fossil, representing a new tribe (Jantaritambiini Szwedo, 2000). Some years later Shcherbakov (2006) transferred two other fossil species, already described in 1856 by Germar and Berendt and formerly reported as Cixiidae, into Jantaritambiini. Since then only a few new other representatives were described. They are remarkably diversified into five, well-differentiated fossil tribes. Three are from Elicinae Melichar, 1915, Austrini Szwedo and Stroiński, 2010, Patollini Szwedo and Stroiński, 2013 and Gedanotropidini Szwedo and Stroiński, 2017, all described from the Eocene Baltic amber, and the extinct genus Tritophania Jacobi, 1938 placed in the modern Elicini (Szwedo and Stroiński, 1999, 2017). Two are from Tropiduchinae Stål, 1866, Jantaritambiini Szwedo, 2000 from the Eocene Baltic amber and Emilianini Shcherbakov, 2006 from Colorado, USA.

Precise dating for the Eocene Baltic amber tribes is still debated (Szwedo and Drohojowska, 2016; Wolfe et al., 2016; Grimaldi and Ross, 2017). Ages include the Upper Eocene (in the Bartonian/ Priabonian: $37.7 \pm 3 \mathrm{Ma}$ ) according to Perkovsky et al. (2007), middle Eocene in the Lutetian (44.1 \pm 1.1 Ma, Wappler, 2003, 2005) or even $50 \mathrm{Ma}$ (Weitschat and Wichard, 2010). Emiliana, collected 
from the Green River Formation, is not older than Baltic amber specimens; it was collected from the Parachute Creek Member in Colorado (Shcherbakov, 2006) dated as either Uintan (46.2-40.4 Ma, Paleobiology Database, 2019) or Lutetian (47.8$41.2 \mathrm{Ma})$. Seeteascanopia gen. nov., therefore, appears therefore as the second confirmed New World fossil Tropiduchidae described, excluding the Neommatissini fossil previously mentioned (Shcherbakov, 2006) that still awaits its formal description and confirmed placement.

Seeteascanopia gen. nov. was excavated from the La Bucara mines, the amber originating from a late early to early middle Miocene (around $16 \mathrm{Ma}$, Burdigalian), lowland environment in Northern Hispaniola. At that time Hispaniola was part of an island-archipelago still connected to Puerto Rico and probably eastern Cuba, but already separated from the Virgin Islands (Iturralde-Vinent, 2001). In the Greater Antilles in the early Miocene, Hymenaea trees - presumably $H$. protera Poinar (Fabaceae) - were likely abundant on the slopes bordering a central highland area and produced large amounts of resin (Iturralde-Vinent, 2001) in correlation with the occurrence of a warm climatic maximum (Iturralde-Vinent, 2006) that facilitated insect trapping. These paleoenvironmental conditions are in line with the present ones observed in the southern margin of Paricanini distribution that belong to subtropical moist forest and tropical rain forest terrestrial biomes (Porse, 2008).

\section{Biogeography}

Tropiduchidae have been widely studied in recent years. The system of classification proposed by Fennah (1982) of 15 tribes has been revised into two subfamilies, 25 tribes and seven subtribes (Bourgoin, 2019). However, this morphological classification remains mainly arbitrary and still need to be tested and based on a phylogenetic analysis. Indeed, with the notable exception of Tropiduchini (Wang et al., 2017), the phylogenetic structure of the family and sub-clades that could frame (or even suggest) any global understanding of the group is completely absent. In such a context, it appears difficult to propose any convincing scenario that might give account of this unexpected bipolar Neotropical-Southeast Asia distribution of Paricanini; nevertheless, two hypotheses might be suggested.

Tropiduchidae are distributed in all major biological regions of the world, and their centre of origin remains obscure. While the oldest tropiduchid fossils are not older than Lutetian, molecular cali- bration indicates that the family likely originated in the Upper Cretaceous (Bourgoin et al., 2018; Szwedo, 2018) and, as for Issidae or Caliscelidae, the family was probably already well diversified by the Eocene (op. cit.), representing a diversified Laurasian lineage (Davis et al., 2002). This result is supported by the noticeable diversity of Eocene Tropiduchidae fossil tribes already described from both Palearctic and Nearctic as attested by the tribe Emilianini (Shcherbakov, 2006).

According to the estimated date of origin of Tropiduchidae in the Upper Cretaceous, Palaeocene Palearctic-Nearctic dispersions could have taken place at different periods using different highlatitude land bridges (Brikiatis, 2014): the North Atlantic De Geer route (70.7-63 m.y.a.), the Western Palearctic-Eastern Nearctic Thulean route (57 and 56 m.y.a.) or the Eastern Palearctic-Western Nearctic connections via the Beringian route (65.6 and 58 m.y.a.) (Brikiatis, 2014). The current bipolar distribution of such a Paleocene Paricanini lineage would, therefore, be the result of reduction of an originally wider area of distribution reached during the late Paleocene-early Eocene by dispersions and migrations (Davis et al., 2002). At this time, the climate was warmer and more uniform (Zachos et al., 2001, 2008; Mudelsee et al., 2014), and land connections between North America and Europe were still present and covered with tropical forests.

Islands of the Greater Antilles were isolated from mainland North America since their emergence in the Early Cretaceous and only briefly connected to South America along the Greater Antilles-Aves Ridge (Gaarlandia overland bridge) during the late Eocene to the early Oligocene (3335 m.y.a., Iturralde-Vinent, 2006). An over-sea dispersion from the North American mainland to Hispaniola would, therefore, be the most plausible scenario for the occurrence of Paricanini in the Caribbean.

This Palaeocene scenario was already suggested for the recently described Caliscelidae fossil genus Quizqueiplana Bourgoin and Wang, 2015 (Bourgoin et al., 2016) also collected from La Bucara mines. However, Paricanini are exclusively reported from Southeast Asia - versus Caliscelidae Augilini, which are additionally known from Madagascar (Bourgoin et al., 2016) - as well as its closer representatives of Ipsorisini (Fennah, 1982), which might represent a younger lineage of Oriental origin. Accordingly, using a more recent counter-clock dispersion through a younger Beringian route between the Eastern Palearctic and Western Nearctic that was available during the 
Oligocene and Miocene (Sanmartín et al., 2001), Paricanini might represent another example of the Cenozoic Beringian Dispersal Hypothesis (Guo et al., 2012). Later, they reached the Great Antilles by over-sea dispersion.

In absence of a better phylogenetic framework, dating and orientating any dispersal scenario that would have allowed preferring either the Palaeocene or the Oligocene dispersal remains impossible. But parsimoniously, the Oligocene scenario is currently accepted. For the same reasons, both scenarios should be also suggested to explain the as yet undescribed Dominican tropiduchid Neommatissini fossil genus (Shcherbakov, 2006).

\section{CONCLUSIONS}

Seateascanopia gen. nov. attests to the diversity of Tropiduchidae and Paricanini in the Caribbean during the Miocene. However, the family was already well diversified in the Eocene and distributed in the Nearctic (Emilianini), representing a Laurasian lineage. We provisionally suggest that Paricanini and Neommatissini-young lineages of Oriental origin-likely dispersed to the Nearctic during the Oligocene according to the Cenozoic Beringian Dispersal Hypothesis (Guo et al., 2012) before an over-sea dispersion to Hispaniola at least 16 m.y.a. However, an older Palaeocene scenario with Tropiduchidae and Paricanni already well diversified during late Palaeocene - early Eocene cannot be excluded. In this case, climate oscillations and graduate general cooling during the late Eocene - Oligocene pushed the lineages that reached Hispaniola south no later than 16 m.y.a. also by an over-sea dispersion.

These two hypotheses need to be tested in the light of a phylogeny of the tropiduchid family, by anchoring the Paricanini clade (and Neommatissini) in this bioregion since at least Early-Middle Miocene (Burdigalian). However, a robust phylogeny of the Tropiduchidae is wanting. These fossils highlight the importance of reporting the past occurrences and distribution of such isolated taxa for future molecular calibration analyses but also in allowing a better understanding of the shape of modern communities.

\section{ACKNOWLEDGMENTS}

The authors express their warmful thanks to Mr. A. Brown for the gift of the specimen to the first author (TB), which is now deposited in MNHN collections. The work on which this paper is based was supported by the following sources: the National Natural Science Foundation of China (grant numbers 31270043 and 30900145), awarded to RRW. This paper is a contribution to the project "Evolution and disparity of Tropiduchidae (Insecta: Hemiptera: Fulgoromorpha)" conducted as the Polish-Chinese joint research project for the years $2013-2015$ by the agreement between Polish Academy of Sciences and Chinese Academy of Sciences.

\section{REFERENCES}

Amyot, C.J.B. and Serville, J.G. 1843. Homoptères. Homoptera Latr. Deuxième partie. Histoire Naturelle des insectes. Hémiptères. Librairie Encyclopédique de Roret, Paris. https://doi.org/ 10.5962/bhl.title.8471

Baker, C.F. 1915. Notices of certain Philippine Fulgoridae, one being of economic importance. Philippine Journal of Science, 10:137-144.

Bourgoin, T. 1993. Female genitalia in Hemiptera Fulgoromorpha, morphological and phylogenetic data. Annales de la Société Entomologique de France, 29:225-244.

Bourgoin, T. 2019. FLOW (Fulgoromorpha Lists on The Web): A World Knowledge Base Dedicated to Fulgoromorpha. Version 8, updated 7th January 2019. https://www.hemipteradatabases.org/flow/

Bourgoin, T., Guilbert, E., and Wang, M.L. 2018. Issidae molecular K-libration. 8th European Hemiptera Congress \& 11th International Workshop on Leafhoppers and Planthoppers of Economic Importance, 24-29th June 2018, Zawiercie, Katowice Poland 2018, Katowice, p. 36.

Bourgoin, T. and Huang, J. 1990. Morphologie comparée des genitalia mâles des Trypetimorphini et remarques phylogénétiques (Hemiptera: Fulgoromorpha: Tropiduchidae). Annales de la Société Entomologique de France, 26:555-564. 
Bourgoin, T., Wang, R.-R., Asche, M., Hoch, H., Soulier-Perkins, A., Stroiński, A., Yap, S., and Szwedo, J. 2015. From micropterism to hyperpterism: recognition strategy and standardized homology-driven terminology of the forewing venation patterns in planthoppers (Hemiptera: Fulgoromorpha). Zoomorphology, 134:63-77. https://doi.org/10.1007/s00435-014-0243-6

Bourgoin, T., Wang, R.-R., and Gnezdilov, V.M. 2016. First fossil record of Caliscelidae (Hemiptera: Fulgoroidea): a new Early Miocene Dominican amber genus extends the distribution of Augilini to the Neotropics. Journal of Systematic Palaeontology, 14:211-218. https://doi.org/10.1080/14772019.2015.1032376

Brikiatis, L. 2014. The de Geer, Thulean and Beringia routes: key concepts for understanding early Cenozoic biogeography. Journal of Biogeography, 41:1036-1054. https://doi.org/ 10.1111/jbi.12310

Brummitt, R.K. 2001. World Geographical Scheme for Recording Plant Distributions. Edition 2. TDWG. https://github.com/tdwg/wgsrpd/blob/master/109-488-1-ED/2nd\%20Edition/ TDWG_geo2.pdf

Carpenter, F.M. 1992. Hexapoda. Treatise on Invertebrate Paleontology, Part R, Arthropoda 4 (3, 4). Geological Society of America and University of Kansas, Boulder and Lawrence. https:// doi.org/10.17161/dt.v0i0.5370

Constant, J. and Pham, H.T. 2014. A new species of Paricanoides Liang, 2003 from Northern Vietnam (Hemiptera: Fulgoromorpha: Tropiduchidae). Belgian Journal of Entomology 24:1-9.

Davis, C.C., Bell, C.D., Mathews, S., and Donoghue, M.J. 2002. Laurasian migration explains Gondwanan disjunctions: Evidence from Malpighiaceae. Proceedings of the National Academy of Sciences, 99:6833-6837. https://doi.org/10.1073/pnas.102175899

Distant, W.L. 1906. Rhynchotal notes. XL. Annals and Magazine of Natural History. London. (Ser. 7), 18:349-356. https://doi.org/10.1080/00222930608562627

Evans, J.W 1956. Paleozoic and Mesozoic Hemiptera (Insecta). Australian Journal of Zoology, 4:165-258. https://doi.org/10.1071/zo9560165

Fennah, R.G. 1945a. The Fulgoroidea, or lanternflies, of Trinidad and adjacent parts of South America. Proceedings of the United States National Museum. Washington, 95:411-520. https://doi.org/10.5479/si.00963801.95-3184.411

Fennah, R.G. 1945b. The Tropiduchidae of the Lesser Antilles (Homoptera: Fulgoroidea). Proceedings of the Entomological Society of Washington, 47:137-167.

Fennah, R.G. 1945c. Tropiduchidae and Kinnaridae from the Greater Antilles (Homoptera: Fulgoroidea). Psyche, 52:119-138. https://doi.org/10.1155/1945/81807

Fennah, R.G. 1982. A tribal classification of the Tropiduchidae (Homoptera: Fulgoroidea), with the description of a new species on tea in Malaysia. Bulletin of Entomological Research, 72:631-643. https://doi.org/10.1017/s0007485300008658

Foster, G.L., Lear, C.H., and Rae, J.W.B. 2012. The evolution of $\mathrm{pCO}_{2}$, ice volume and climate during the middle Miocene. Earth and Planetary Science Letters, 341-344:243-254. https:// doi.org/10.1016/j.epsl.2012.06.007

Germar, E.F. and Berendt, G.C. 1856. Die im Bernstein befindlichen Hemipteren und Orthopteren der Vorwelt. p. 1-40. In Berendt, G.C. (ed.), Die im Bernstein befindlichen organischen Reste der Vorwelt. Commission der Nicholai'schen Buchhandlung, Berlin.

Gnezdilov, V.M. 2013. Contribution to the taxonomy of the family Tropiduchidae Stål (Hemiptera, Fulgoroidea) with description of two new tribes from Afrotropical Region. Deutsche entomologische Zeitschrift, 60:179-191.

Gnezdilov, V.M., Bartlett C.R., and Bourgoin T. 2016. A new tribe of Tropiduchidae (Hemiptera: Fulgoroidea) with revision of the genus Buca and description of asymmetric hind leg spinulation. Florida Entomologist, 99:406-416. https://doi.org/10.1653/024.099.0311

Grimaldi, D.A. and Ross A.J. 2017. Extraordinary Lagerstätten in amber, with particular reference to the Cretaceous of Burma, p. 287-342. In Fraser N.C. and Sues H.-D. (eds.), Terrestrial Conservation Lagerstätten. Dunedin, Edinburgh.

Guérin-Méneville, F.E. 1856. Segunda, Seccion. Homopterous. Historia fisica politica y natural de la Isla de Cuba. Segunda Parte, Historia Natural, 7:178-182.

Guo, P., Liu, Q., Xu, Y., Jiang, K., Hou, M., Ding, L., Pyron, R.A., and Burbrinkg, F.T., 2012. Out of Asia: Natricine snakes support the Cenozoic Beringian Dispersal Hypothesis. Molecular Phylogenetics and Evolution, 63:825-833. https://doi.org/10.1016/j.ympev.2012.02.021

Hamilton, K.G.A. 1992. Lower Cretaceous Homoptera from the Koonwarra Fossil Bed in Australia with a new superfamily and synopsis of Mesozoic Homoptera. Annals of the Entomological Society of America, 85:423-430. https://doi.org/10.1093/aesa/85.4.423 
Handlirsch, A. 1904. Uber einige Insektenreste aus der Permoformation Russlands. Zapiski Imperatorskoj Akademii Nauk SPb. Fiziko-matematicheskoe Otdelenie, Ser 8, 16:1-8.

Henrot, A.-J., Utescher, T., Erdei, B., Dury, M., Hamon, N., Ramstein, G., Krapp, M., Herold, N., Goldner, A., Favre, E., Munhoven G., and François, L. 2017. Middle Miocene climate and vegetation models and their validation with proxy data. Palaeogeography, Palaeoclimatology, Palaeoecology, 467:95-119. https://doi.org/10.1016/j.palaeo.2016.05.026

Holt, B.G., Lessard, J.P., Borregaard, M.K., Fritz, S.A., Araújo, M.B., Dimitrov, D., Fabre, P.H., Graham, C.H., Graves, G.R., Jønsson, K.A., Nogués-Bravo, D., Wang, Z., Whittaker, R.J., Fjeldsa, J., and Rahbek, C. 2013. An update of Wallace's zoogeographic regions of the world. Science, 339:74-78. https://doi.org/10.1126/science.1228282

Iturralde-Vinent, M.A. 2001. Geology of the amber-bearing deposits of the Greater Antilles. Caribbean Journal of Science, 37:141-167.

Iturralde-Vinent, M.A. 2006. Meso-Cenozoic Caribbean paleogeography: Implications for the historical biogeography of the region. International Geology Review, 48:791-827. https:// doi.org/10.2747/0020-6814.48.9.791

Jacobi, A. 1938. Eine neue Bernsteinzikade (Rhynchota, Homoptera). Sitzungsberichte der Gesselschaft naturforschender Freunde zu Berlin, 15: 188-189.

Lewis, S.E. and Heikes P.M. 1991. A catalog of fossil sites from the Tertiary of the United States. Occasional Papers in Paleobiology at St. Cloud State University, 5:1-487.

Liang, A.-P. 2003. A new genus of Tropiduchidae (Hemiptera: Fulgoroidea) from China and Vietnam, with description of eggs. Florida Entomologist, 86:361-369. https://doi.org/10.1653/ 0015-4040(2003)086[0361:angoth]2.0.co;2

Linnaeus, C. 1758. Systema Nature per Regna Tria Naturae, Secundum Classes, Ordines, Genera, Species, cum Caracteribus, Differentiis, Synonymi, Locis. Tomus I. Editio decima, reformata. L. Salvii, Holmiae. https://doi.org/10.5962/bhl.title.542

Melichar, L. 1914. Monographie der Tropiduchinen (Homoptera). Verhandlungen des Naturforschenden Vereins in Brünn, 53:1-145.

Melichar, L. 1915. Monographie der Lophopinen. Annales Historico-Naturales Musei Nationalis Hungarici, 13:337-385.

Metcalf, Z.P. and Bruner, S.C. 1930. Cuban Fulgorina. 1. The families Tropiduchidae and Acanaloniidae. Psyche, 37:395-424. https://doi.org/10.1155/1930/86504

Metcalf, Z.P. and Wade, V. 1966. A Catalogue of the Fossil Homoptera (Homoptera: Auchenorrhyncha). General Catalogue of the Homoptera. A Supplement to Fascicle IMembracidae of the General Catalogue of the Hemiptera. General Catalogue of the Homoptera. Contribution from the Entomology Department, North Carolina Agricultural Experiment Station, Raleigh, N.C., U.S.A. North Carolina State University.

Mudelsee, M., Bickert, T., Lear, C.H., and Lohmann, G. 2014. Cenozoic climate changes: A review based on time series analysis of marine benthic $\delta^{18} \mathrm{O}$ records. Reviews of Geophysics, 52:333-374. https://doi.org/10.1002/2013rg000440

Muir, F.A.G. 1913. On some new Fulgoroidea. Proceedings of the Hawaiian Entomological Society, 2:237-269.

Muir, F.A.G. 1923. On the classification of the Fulgoroidea (Homoptera). Proceedings of the Hawaiian Entomological Society, 5:205-247.

Muir, F.A.G. 1924. New and little-know Fulgorids from the West Indies (Homoptera). Proceedings of the Hawaiian Entomological Society. 5:461-472.

Paleobiology Database 2019. https://paleobiodb.org/

Penney, D. 2010. Dominican amber, p. 22-41. In Penney, D. (ed.), Biodiversity of Fossils in Amber from the Major World Deposits. Siri Scientific Press, Manchester.

Perkovsky, E.E., Rasnitsyn, A.P., Vlaskin, A.P., and Taraschuk, M.V. 2007. A comparative analysis of the Baltic and Rovno amber arthropod faunas: representative samples. African Invertebrates, 48:229-245.

Porse, S. 2008. Image: Vegetation.png, CC BY-SA 3.0 https://commons.wikimedia.org/w/ index.php?curid $=3344457$

Sanmartín, I., Enghoff, H., and Ronquis, T.F. 2001. Patterns of animal dispersal, vicariance and diversification in the Holarctic. Biological Journal of the Linnaean Society, 73:345-390. https:/ /doi.org/10.1111/j.1095-8312.2001.tb01368.x

Scudder, S.H. 1878. The fossil insects of the Green River shales. Bulletin of the United States Geological and Geographical Survey of the Territories, 4:747-776. https://doi.org/10.3133/ 70159424 
Shcherbakov, D.E. 1984. Sistema i filogeniya permskikh Cicadomorpha (Cimicida, Cicadina). [In Russian: Systematics and phylogeny of Permian Cicadomorpha (Cimicida, Cicadina)] Palaeontologicheskii Zhurnal, 18:87-97.

Shcherbakov, D.E. 2006. The earliest find of Tropiduchidae (Homoptera: Auchenorrhyncha), representing a new tribe, from the Eocene of Green River, USA, with notes on the fossil record of higher Fulgoroidea. Russian Entomological Journal, 15:315-322.

Spinola, M. 1839. Essai sur les Fulgorelles, sous-tribu de la tribu des Cicadaires, ordre des Rhyngotes. Annales de la Société Entomologique de France, 8:133-454.

Stål, C. 1859. Novae quaedam Fulgorinorum formae speciesque insigniores. Berliner Entomologische Zeitschrift. Berlin, 3:313-327. https://doi.org/10.1002/mmnd.18590030405

Stål, C. 1866. Hemiptera Homoptera Latr. Hemiptera Africana, 4. Holmiæ : Ex officina Norstedtiana. https://doi.org/10.5962/bhl.title.8566

Stroiński, A., Wang, R.-R., Bourgoin, T., Liang, A.-P., and Szwedo, J. 2015. Review of the Paricanini (Hemiptera: Fulgoromorpha: Tropiduchidae). Annales Zoologici Warszawa, 65:579-597. https://doi.org/10.3161/00034541anz2015.65.4.006

Szwedo, J. 2000. First fossil Tropiduchidae with a description of a new tribe Jantaritambini from Eocene Baltic amber (Hemiptera: Fulgoroidea). Annales de la Société Entomologique de France, 36:279-286.

Szwedo, J. 2018. The unity, diversity and conformity of bugs (Hemiptera) through time. Earth and Environmental Science Transactions of the Royal Society of Edinburgh, 107:109-128. https://doi.org/10.1017/s175569101700038x

Szwedo, J. and Drohojowska, J. 2016. A swarm of whiteflies-the first record of gregarious behavior from Eocene Baltic amber. The Science of Nature, 103:35. https://doi.org/10.1007/ s00114-016-1359-y

Szwedo, J. and Stroiński, A. 1999. Redescription of Tritophania patruelis Jacobi, 1938 from Eocene Baltic amber (Hemiptera: Nogodinidae). Annales Zoologici, 49:203-207.

Szwedo, J. and Stroiński, A. 2010. Austrini - a new tribe of Tropiduchidae planthoppers from the Eocene Baltic amber (Hemiptera: Fulgoromorpha). Annales de la Société entomologique de France, 46:132-137. https://doi.org/10.1080/00379271.2010.10697648

Szwedo, J. and Stroiński, A. 2013. An extraordinary tribe of Tropiduchidae from the Eocene Baltic amber (Hemiptera: Fulgoromorpha: Fulgoroidea). Zootaxa, 3647:371-381. https:// doi.org/10.11646/zootaxa.3647.2.8

Szwedo, J. and Stroiński, A. 2017. Who's that girl? The singular Tropiduchidae planthopper from the Eocene Baltic amber (Hemiptera: Fulgoromorpha). Palaeontologia Electronica, 20.3.60A:1-20. https://doi.org/10.26879/784 palaeo-electronica.org/content/2017/2079-tropiduchid-from-baltic-amber

Szwedo, J., Bourgoin, T., and Lefèbvre, F. (eds.). 2004. Fossil Planthoppers (Hemiptera: Fulgoromorpha) of the World. An Annotated Catalogue with Notes on Hemiptera Classification. Studio 1, Warsaw. https://www.researchgate.net/publication/235343307

Tillyard, R.J. 1920. Mesozoic insects of Queensland. No.7. Hemiptera Homoptera with a note on the phylogeny of the suborder. Proceedings of the Linnean Society of New South Wales, (1919), 44:857-896.

Uhler, P.R. 1901. Some new genera and species of North American Hemiptera. Proceedings of the Entomological Society of Washington, 4:507-515.

Van Duzee, E.P. 1908. Studies in North American Fulgoridae. Proceedings of the Academy of Natural Sciences of Philadelphia (1907), 59:467-498.

Walker, F. 1857. Catalogue of the Homopterous insects collected at Sarawak, Borneo, by Mr. A.R. Wallace, with descriptions of new species. Journal of the Proceedings of the Linnaean Society. London, 1:141-175. https://doi.org/10.1111/j.1096-3642.1857.tb00966.x

Wallace, A.R. 1876. The Geographical Distribution of Animals: with a Study of the Relations of Living and Extinct Faunas as Elucidating the Past Changes of the Earth's Surface. Macmillan, London. https://doi.org/10.5962/bhl.title.46581

Wang, R.-R., Li, X. L., Szwedo, J., Stroiński, A., Liang, A.-P., and Bourgoin, T. 2017. Testing Tropiduchini Stål 1866 (Hemiptera: Tropiduchidae) monophyly, a young inter-tropical taxon of mainly insular species: taxonomy, distribution patterns and phylogeny, with the description of a new genus from Papua New Guinea. Systematic Entomology, 42:359-378. https://doi.org/ 10.1111/syen.12219

Wappler, T. 2003. Die Insekten aus dem Mittel-Eozän des Eckfelder Maares, Vulkaneifel. Mainzer Naturwissenschaftliches Archiv, 27:1-234. 
Wappler, T. 2005. The age of Baltic amber: Could Eckfeld resolve this problem? Fossils X3, 3rd International Congress of Palaeoentomology with 2nd International Meeting on Palaeoarthropodology and 2nd World Congress on Amber and Its Inclusions. Programme and Abstracts, Pretoria, p. 53.

Weitschat, W. and Wichard, W. 2010. Baltic amber, p. 80-115. In Penney, D. (ed.), Biodiversity of Fossils in Amber from Major World Deposits. Siri Scientific Press, Manchester.

Wolfe, A.P., Mckellar, R.C., Tappert, R., Sodhi, R.N.S., and Muehlenbachs, K. 2016. Bitterfeld amber is not Baltic amber: Three geochemical tests and further constraints on the botanical affinities of succinite. Review of Palaeobotany and Palynology, 225:21-32. https://doi.org/ 10.1016/j.revpalbo.2015.11.002

Wu, R.J.C. 1996. Secrets of a Lost World. Dominican Amber and its Inclusions. Santo Domingo, Dominican Republic.

Zachos, J.C., Dickens, G.R., and Zeebe, R.E. 2008. An Early Cenozoic perspective on greenhouse warming and carbon-cycle dynamics. Nature, 451:279-283. https://doi.org/ 10.1038/nature06588

Zachos, J.C., Pagani, M., Sloan, L., Thomas, E., and Billups, K. 2001. Trends, rhythms, and aberrations in global climate 65 Ma to present. Science, 292:686-693. https://doi.org/ 10.1126/science.1059412 